\title{
How the GCC Economic Crises Effect Labor Migration: Evidence from Pakistan
}

\author{
Yasir Khan ${ }^{1} \Varangle$ \\ Wang Mingyi ${ }^{2}$
}

'Ph.D. Scholar School of Economics and Management Southeast University 211198 China Email:khanyasir@seu.edu.cn

${ }^{2}$ Ph.D. Professor School of International Economics and Trade, Shandong University of Finance \& Economics, China

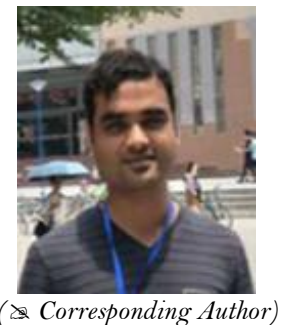

\begin{abstract}
Migrant workers have participated in promoting economic growth and prosperity and the generation of wealth in countries of destination. The Gulf Cooperation Council (GCC) which is comprised of six countries such as Saudi Arabia, UAE, Qatar, Kuwait, Bahrain, and Oman have been historically and traditionally job market for Pakistani workers. Labor migration and its relationship to economic growth and employment have received increasing attention because of increasing demand for labor, higher salaries, economic and political stability. Using a case study, we focus on the impact and relationship of labor migration with macroeconomic indicators such as Gross Domestic Product (GDP), unemployment, and inflation rate. Limited employment opportunities, the weak economy, and political instability are the factors leading labor migration from Pakistan. Consequently, the government of Pakistan considered labor migration primarily as an employment sector and encourage labor migration to solve economic problems in the country. We analyze the impact of labor migration on (GDP), Inflation rate and unemployment in Pakistan with the help of time series data from 1971-2016. The result to have showed a positive and significant relationship between labor migration and GDP, while a negative but significant relationship with unemployment. On the other hand, there is no relationship between labor migration and inflation rate. we found that the GCC economic crises actually caused significant influence on labor migration in the case of Pakistan.
\end{abstract}

Keywords: Foreign direct investment (FDI), Pakistan, GCC, GDP, Unemployment, Inflation rate, VECM.

Citation | Yasir Khan; Wang Mingyi (2018). How the GCC Economic Crises Effect Labor Migration: Evidence from Pakistan. Asian Journal of Economics and Empirical Research, 5(2): 139-146. History:

Received: 29 June 2018

Revised: 13 August 2018

Accepted: 4 September 2018

Published: 21 September 2018

Licensed: This work is licensed under a Creative Commons

Attribution 3.0 License (c) DEr

Publisher:Asian Online Journal Publishing Group
Contribution/Acknowledgement: Both authors contributed to the conception and design of the study.

Funding: This study received no specific financial support.

Competing Interests: The authors declare that they have no conflict of interests.

Transparency: The authors confirm that the manuscript is an honest, accurate, and transparent account of the study was reported; that no vital features of the study have been omitted; and that any discrepancies from the study as planned have been explained.

Ethical: This study follows all ethical practices during writing.

\section{Contents}

1. Introduction

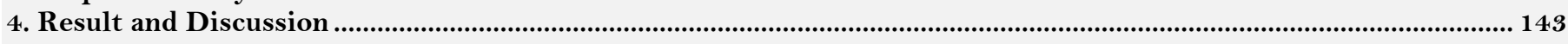

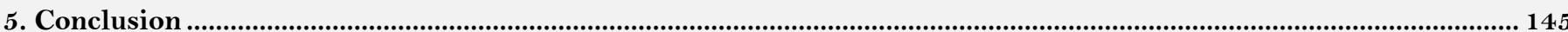

References. 


\section{Introduction}

Labor migration is an integral part of Pakistan economy. Over the past four decades, there are 8 million Pakistanis migrated abroad through the formal channel for employment. The labor migration level from Pakistan reached a new peak after 2011. In the five-year plan from 2011-2015, more than 3 million Pakistani labor lift the country for overseas employment. The migrant workers have significantly contributed to Pakistan's development through the remittances of their earnings. Moreover, labor migration is benefited for Pakistani labor in terms of learning new skills and knowledge through other social assets they required while working overseas. Labor form the poor to the rich countries have been a significant component of international economic relations to an extent it affects political debate in the developing nations.

Awad (2009) indicates that the demand for migrant workers in some major regions of destination, such as the Gulf Cooperation Council (GCC) countries, has not significantly diminished. This may be due to their still positive financial situations, in turn made possible by reserves accumulated in recent years because of high oil prices. The major component to drive labor is international wage differences such moments, vast migration and labor mobility as a heterogeneous factor have also been the reason for capital formation, unemployment, wage inequality. Labor migration also helps the process of development of poor economies have to do with the expansion of physical, human and capital stock. Many classical models determined that in the short-run is to be paid higher wages in order to be attracted to a certain country. On the other hand, in the long-run would cause to equalize wages across nations. According to Keynesian, analyzing that capital was likely to move in the same direction as labor and in effect would intensify and perpetuate the disequilibrium between the gaining and losing areas.

Jonathan Addelton (The Gulf Migration and Pakistan) had determined that a combination of economic and culture motives was responsible for mobility for mobility of labor from South Asia to Gulf prior to the $20^{\text {th }}$ century. Two phases of Pakistani labor migration to the Gulf describes that the third phase of migration which began around 1970 built on an already existing set of family and cultural links. The major destination for Pakistani labor is United Arab Emirates (UAE), Saudi Arabia, Kuwait, Bahrain, and Europe. Khan et al. (2018) found the long-run relationship between foreign direct investment (FDI) and economic growth using time series data for Pakistan form 1978-2016. Koser (2010) most GCC countries report declines in economic growth, this is mainly due to decreasing oil prices after soaring oil-prices in 2008.

\section{Number of Migrated Labor from Pakistan}

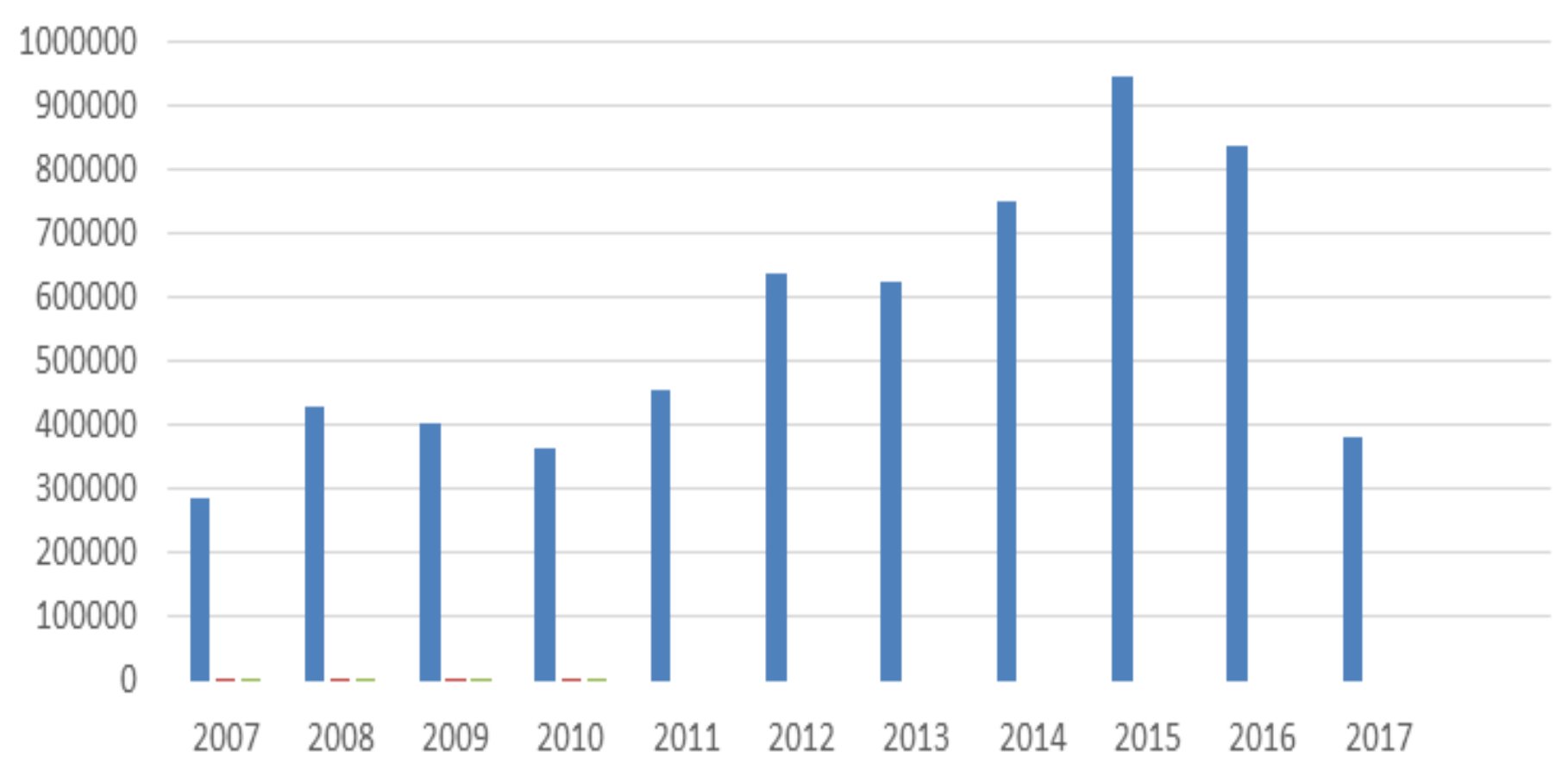

Figure-1. Number of Overseas Labor from Pakistan.

Source: National Bureau of Statistics Pakistan, International Labor Organization

Figure 1 reveals a strong and positive relationship between the overall economic growth of Pakistan and the growth of overseas migration among Pakistani labor. Azam (1995) found that sending remittances of Pakistani labor remarkably supported Pakistan economy. Manpower export to eh middle east began on a large scale in early 1975. Noman (1991) revealed that remittances from the middle east increased dramatically over the past decades. International migration considered as an ever-growing phenomenon that has important development implications for both sending and receiving countries.

Halfacree (2004) stress that a range of non-economic macro-scale variables could be also influence migration. For sending country labor migration and the resulting remittances lead to increase incomes and poverty reduction, promote economic development and improved health and educational outcomes. Fassmann and Hintermann (1998) suggest that determining the potential for migration is a complicated issue and especially due to political sensitivities, need a rigorous research approach. Many developing nations are also major recipients of international migrants, they face challenges of integration of immigrants, job competition between migrant and native workers, and fiscal costs associated with the provision of social services to the migrants. Remittances have been found to have an income stabilizing effect at both macroeconomic levels and at the household level. 
Table-1. Economic Push and Full Factors of Migration

\begin{tabular}{l|l}
\hline Push Factor (native places) & Pull Factor (foreign destinations) \\
\hline High unemployment rate & High demand of labor \\
\hline Relatively low wages & High income level per capita (GDP) \\
\hline Relatively low-income level per capita (GDP) & High wages \\
\hline Relative high taxes & Relative low taxes \\
\hline Relative high consumer price index (CPI) & Relative low consumer price index (CPI) \\
\hline Low investment & High investment \\
\hline Source: Ministry of trade and Commerce Pakistan &
\end{tabular}

Mixon (1992) revealed that the process of migration starts when the benefits of these factors exceed costs. Kumpikaite and Zickute (2012) analyzed when the percentage of unemployment increases, emigration increase and vice versa. Glinskienė and Petuškienė (2009) higher productivity and lower emigration could mean a reduction of long-term unemployment. Sending more labor migrants to other countries could decrease unemployment and increase the country economic growth by sending remittances. Sjaastad (1962) analyzed that migration can be understood an investment decision to realize differential outcomes on human capital in terms of different economic spaces.

8

7

6

5

4

2

1

0

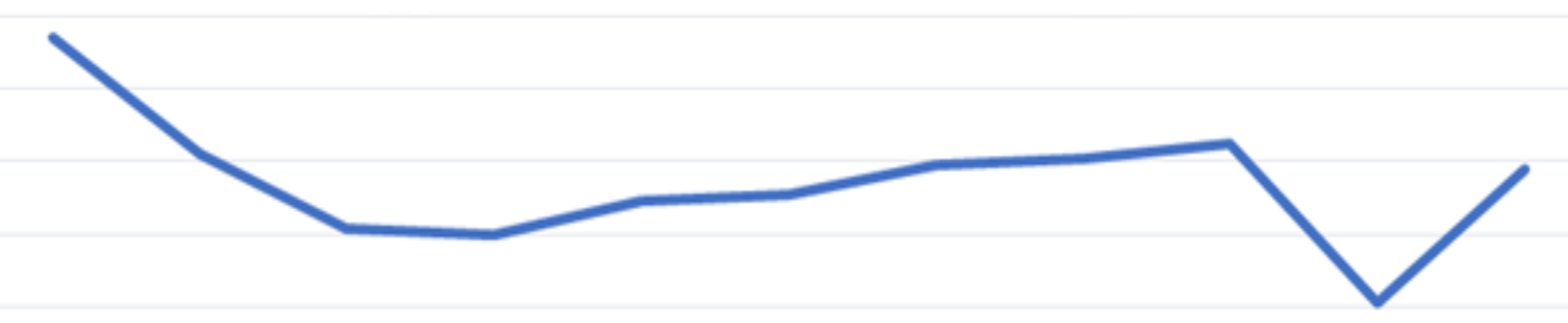

1
2005
2006

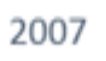
$\begin{array}{lllll}2008 & 2009 & 2010 & 2011 & 2012\end{array}$
2013
2014
2015
Figure-2. Unemployment rate in Pakistan in Percent

Source: National Bureau of Statistics Pakistan

\section{Literature Review}

Labor migration from Pakistan has been increased significantly in the last two decades. Labor from Pakistan has contributed hugely to the country economy by sending remittances. Kumpikaite and Zickute (2012) the minimum wage rate influences significantly change the migration process. Valiūnienè (2016) found that one of the most important factors are better employment possibilities with better wages. Otoiu et al. (2014) the process of migration is not new by itself and is studied by many research scholars. Migration is a phenomenon that has major societal, regional, national, and transactional consequences. Chiswick et al. (2005) found highly-skilled immigrants and for immigrants from countries where skills are readily transferable to the host. In the case of high-skilled migrants, the countries with different labor markets, the mobility from one country to another is more likely to involve downward mobility, but as with highly skilled labor migrants, as location-specific human capital is obtained, upward mobility is possible.

Mixon (1992) found that the gross domestic product (GDP) per capita allows comparing the international level of development. Therefore, it is significantly acknowledged that a higher development could a prerequisite for a reduction of the extent of migration. Meyer and Shera (2017) suggested that the impact of remittances on economic growth increase the GDP of 6 high remittances receiving countries (Albania, Bulgaria, Macedonia, Moldova, Romania and Bosnia Herzegovina during the period of 1993-2013 using panel data. suggest that Pakistan need to improve and develop the production technology of primary and secondary goods to high tech products and industries where international growth is concentered. Hirose (1994) found that labor migration and direct investment are becoming the focus of attention and careful analysis due to rapid changes in the economic changes. Phongpaichit (1990); Root (1994) determined that FDI has a positive impact on exports the reason is that overseas investors and firms taking of abundant and inexpensive factor of production of the host nation which economizes unit cost and thus increases its exports. Hailu (2010) analyzed the relationship between FDI and trade (export, import) of African countries for the time period 1980-2007. The relationship between FDI and import is found out positive and significant. Firpo et al. (2011); Ottaviano et al. (2013) indicates that international trade appears to be a decisive factor. In particularly, typically held by middle-skill workers are increasingly offshored.

Davidson et al. (2008) found that the roles of efficiency in employment search, they concluded the rate of employment destruction and the ratio of employee turnover in the determination of comparative advantage. Moore and Ranjan (2005) determine that how trade liberalization in a skill-abundant country can reduce the unemployment of skilled workers and increase the unemployment of unskilled workers. Felbermayr et al. (2011) found that incorporate search of unemployment in a one sector model with firm heterogeneity to understand the implications of a bilateral reduction in trade cost on unemployment. Braun and Scheffel (2007) revealed that growing international outsourcing reduce the union wage premium of low skilled workers. 
Artuç and McLaren (2015) found that labor can move across wage difference at a cost. This factor of migration is common and an idiosyncratic component. Krugman (1991) determents that migrants not only follow markets potential, they also affect market potential. Mundell (1961); Kenen (1969); Hughes and McCormick (1994) revealed that labor in extreme high unemployment region can move to low unemployment region, for the purpose to reducing aggregate unemployment and accelerating adjustments to asymmetric regional shocks.

Todaro (1969) his research mostly focused on economic inequalities and macroeconomic trends. He suggests that the new classical approach stress differences in wage and unemployment at the regional and international level. Otrachshenko and Popova (2014) found that the perception to migrate is indeed affected by macroeconomic factors. Combining the impact of life satisfaction and macroeconomic factors reveals a greater propensity to migrate among individuals from the Central and Eastern European countries.

\subsection{Labor Migration from Pakistan}

Labor migration from Pakistan is not a new topic. The surge in labor migration for overseas employment has brought deep changes in the socio-economic fabric of the country. Although the labor migration phenomenon has emerged as an alternative livelihood opportunity for many Pakistani households. With such a huge working-age population in Pakistan, an increasing number of workers have moved to other countries for employment; after India, Pakistan annually sends abroad the second-largest grouping of workers in South Asia, mainly to the Gulf region.

Table-2. Distribution (\%) of Pakistani workers, by country of destination, 1971-2015

\begin{tabular}{l|l|l}
\hline Courtiers & No. of workers & \% share \\
\hline Saudi Arabia & 4325183 & 50.3 \\
\hline United Arab Emirates & 2832941 & 32.9 \\
\hline Oman & 644047 & 7.5 \\
\hline Kuwait & 181441 & 2.1 \\
\hline Bahrain & 142420 & 1.7 \\
\hline Qatar & 123639 & 1.4 \\
\hline Iraq & 70719 & 0.8 \\
\hline Libya & 81145 & 0.9 \\
\hline Republic of Korea & 15431 & 0.2 \\
\hline Malaysia & 66417 & 0.8 \\
\hline Italy & 28033 & 0.3 \\
\hline United States & 4739 & 0.1 \\
\hline United Kingdom & 12142 & 0.1 \\
\hline Rest of the world & 70568 & 0.1 \\
\hline Total & 8598865 & 100.0
\end{tabular}

Pakistan relies heavily on labor migration as an avenue for reducing both unemployment and poverty. Migration is recognized as a central dimension of globalization, touching almost all countries around the world as points of origin, transit or destination for migrants or even all three at once. Since the mid-1970s when dramatically rising oil prices led to an economic boom in the oil-rich countries of the Gulf region, large-scale temporary and circular foreign worker migration has accommodated the associated labor needs.

Pakistani workers have been a large presence in that movement as well as in the flow to other new opportunities in the world, particularly the United Kingdom, North America and Europe. Over the past four decades, more than 8 million Pakistanis moved abroad through the formal channel for employment. Migration from Pakistan reached a new peak after 2011. In the five-year period from 2011 to 2015, more than 3 million people left the country for foreign-based jobs.

\section{Empirical Analysis}

Labor migration $=a_{11}+\beta_{11}$ Total GDP Growth $\left(\right.$ Annual \%) $+\beta_{12}$ Unemployment $+\beta_{13}$ Inflation rate

GDP Growth (Annual \%) $=\mathrm{a}_{21}+\beta_{21}$ labor migration $+\beta_{22}$ Unemployment $+\beta_{23}$ Inflation rate

Unemployment $=\mathrm{a}_{31}+$ Labor Migration $+\beta_{32}$ GDP growth (Annual \%) $+\beta_{33}$ Inflation Rate

Inflation rate $=a_{31}+$ Labor Migration $+\beta_{32}$ GDP growth (Annual \%) $+\beta_{33}$ Unemployment

\subsection{Vector Error Correction Model}

$\Delta \mathrm{y}_{1, \mathrm{t}}=\beta_{\mathrm{y} 0}+\beta_{\mathrm{y} 1} \Delta \mathrm{y}_{\mathrm{t}-1}+\beta_{\mathrm{yp}} \Delta \mathrm{y}_{\mathrm{t}-\mathrm{p}}+\gamma_{\mathrm{y} 1} \Delta_{\mathrm{t}-1}-\lambda_{\mathrm{yp}} \Delta \mathrm{x}_{\mathrm{t}-1}\left(\mathrm{y}_{\mathrm{t}-1}-\alpha_{0}-\alpha_{1} \mathrm{x}_{\mathrm{t}-1)}+\mathrm{v}_{\mathrm{t}} \mathrm{y}^{\mathrm{s}}\right.$

$\Delta \mathrm{x}_{1, \mathrm{t}}=\beta_{\mathrm{x} 0}+\beta_{\mathrm{x} 1} \Delta \mathrm{y}_{\mathrm{t}-1}+\beta_{\mathrm{xp}} \Delta \mathrm{y}_{\mathrm{t}-\mathrm{p}}+\gamma_{\mathrm{x} 1} \Delta_{\mathrm{t}-1-}-\lambda_{\mathrm{xp}} \Delta \mathrm{x}_{\mathrm{t}-1}\left(\mathrm{y}_{\mathrm{t}-1}-\alpha_{0}-\alpha_{1} \mathrm{x}_{\mathrm{t}-1}\right)+\mathrm{v}_{\mathrm{t}} \mathrm{y}$

Where $\mathrm{y}_{\mathrm{t}}=\alpha_{0}+\alpha_{1} \mathrm{x}_{1}$ is the long-run cointegrating relationship between the two variables and $\lambda \mathrm{y}$ and $\lambda \mathrm{x}$ are the error-correction parameters that measure how $\mathrm{y}$ and $\mathrm{x}$ react to deviations from long-run equilibrium. When we apply the VEC model to more than two variables, we must consider the possibility that more than one cointegrating relationship exists among the variables. For example, if $\mathrm{x}, \mathrm{y}$, and $\mathrm{z}$ all tend to be equal in the long run, then $\mathrm{xt}=\mathrm{yt}$ and $\mathrm{yt}=\mathrm{zt}$ (or, equivalently, $\mathrm{xt}=\mathrm{zt}$ ) would be two cointegrating relationships. To deal with this situation we need to generalize the procedure for testing for cointegrating relationships to allow more than one cointegrating equation, and we need a model that allows multiple error-correction terms in each equation. 


\subsection{Labor Mobility}

Labor mobility describes as the consists of changes in the location of workers both across physical space (geographical mobility) to find jobs (occupational mobility). Geographical mobility can be further subdivided into two categories, long-distance mobility and short-term mobility. A Study in Pakistan showed that such economic indicators such as unemployment rate, lower wages, lack of education and skill knowledge have the biggest influence on emigration.

\section{Result and Discussion}

First of all, we concluded the summary statistics of all the variables which comprise of labor migration, Gross Domestic Product (GDP), unemployment, and inflation rate. The data were obtained by World Bank indicators database for the period of 1978-2016. All the variables are in real terms and are expressed in US Dollars. The summary statistics for the all the variables are indicating that the data is equally distributed. The mean for labor migration is 11.68 while coefficient $\beta$ is 1.16 . The mean of Gross Domestic Product (GDP) is 6.61 while the coefficient of $\beta$ is 0.28. On the other hand, the mean value for Inflation rate and unemployment are 2.05 and 1.14 while the value of coefficient $\beta$ is 0.55 and 0.46 respectively.

The study also indicating the Jerque-Bera test for labor migration, GDP, inflation rate, and unemployment is greater than 0.1 suggests the data are equally distributed. Skewness test shows the probability for labor migration, GDP, inflation rate and unemployment are near to zero, while Kurtosis test should be close to 3. Median is described as the central value of series data while the maximum is the highest in a given set of data and minimum is the smallest or lowest value of the data. Finally, the standard deviation is the dispersion of data around the mean and is denoted by sigma.

Table-3. Summery statistics

\begin{tabular}{l|l|l|l|l}
\hline & Migration & GDP & Inflation & Unemployment \\
\hline Mean & 11.6862 & 6.6145 & 2.0551 & 1.4189 \\
\hline Median & 11.7592 & 6.6778 & 2.0597 & 1.4539 \\
\hline Maximum & 13.7606 & 7.0746 & 3.2832 & 2.112 \\
\hline Minimum & 8.1701 & 6.1176 & 0.9319 & 0.5128 \\
\hline Std. Dev & 1.1666 & 0.2853 & 0.5560 & 0.4698 \\
\hline Skewness & -0.9846 & -0.2504 & 0.048 & -0.5506 \\
\hline Kurtosis & 4.7762 & 1.9132 & 2.6303 & 2.2356 \\
\hline Jerque-Bera & 13.6866 & 2.6847 & 0.2739 & 3.3695 \\
\hline Probability & 0.0013 & 0.2612 & 0.8719 & 0.1854 \\
\hline Sum & 585.8813 & 297.65 & 92.4831 & 63.8524 \\
\hline Sum Sq. Dev. & 59.8854 & 3.5816 & 13.6047 & 9.7151 \\
\hline Source: Ministry of trade and Commerce Pakistan, World Bank & &
\end{tabular}

\subsection{Unit Root Test}

First of all, we use the Augmented Dickey-Fuller test, 1979 to check whether the variables are stationary or not. For this hypothesis, the null hypothesis is that the series does not have to the unit root issue. On the other hand, it is important that all variables are stationary before testing hypothesis. we supposed that alternative hypothesis is that series do have a unit root problem. In our study, at the start all the variables having an issue of a unit root at a level, but we examined at first difference, all variables convert into a stationary hence null hypothesis is accepted as series does not have a unit root problem.

Table 4. Johensen cointegration test suggests that the T-Statistics for labor migration, GDP, Inflation rate and unemployment are greater than critical value at 5\%. Therefore, we choose Vector Error Correction Model on the basis of Johansen cointegration test.

Table-4. Unit root test

\begin{tabular}{l|l|l|l|l}
\hline & At level & \multicolumn{2}{l}{ At first Difference } \\
\hline Variable & T-Statistic & Prob* & T-Statistic & Prob $^{*}$ \\
\hline Emigration & 2.23 & 0.99 & -4.36 & 0.000 \\
\hline GDP & 4.47 & 1.000 & -2.91 & 0.004 \\
\hline Inflation rate & -0.76 & 0.37 & -6.93 & 0.000 \\
\hline Unemployment & 0.59 & 0.83 & -9.31 & 0.000 \\
\hline Source: Ministry of trade and Commerce Pakistan, World Bank
\end{tabular}

Table-5. Johansen Cointegration Test

\begin{tabular}{l|l|l|l|l}
\hline Hypothesized No. of CE(s) & Eigenvalue & Trace Statistic & 0.05 Critical Value & Prob.** \\
\hline None $*$ & 0.560787 & 69.55244 & 40.17493 & 0.0000 \\
\hline At most 1 & 0.439724 & 35.81882 & 24.27596 & 0.0012 \\
\hline At most 2 & 0.211323 & 12.06644 & 12.32090 & 0.0551 \\
\hline At most 3 & 0.055316 & 2.333097 & 4.129906 & 0.1495 \\
\hline Source: Ministry of trade and Commerce Pakistan, World Bank
\end{tabular}

CUSUM graph shows the results of mean and variance of coefficient stability. In the study. We examined that variance of the coefficient is stable as the mean is within the straight bound lines. Therefore, all our models are perfect and stable. 


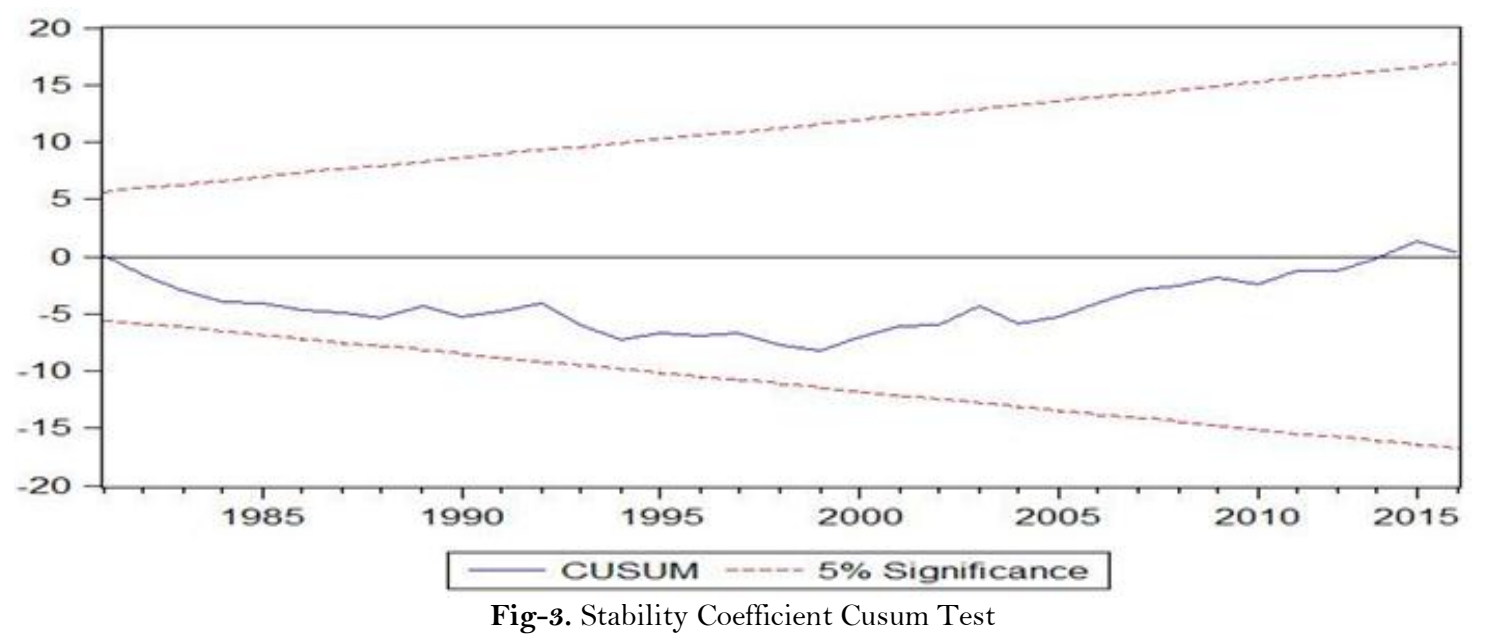

\subsection{Vector Error Correction Model}

Granger and Newbold (1974) was first introduced the Vector Error Correction Model. Many researchers use a vector error correction model for long-run and short-run effects of one-time series on another. We found long runrelationship between labor migration, GDP, and unemployment. In the long-run error correction estimation, the results indicating that the response variable labor migration has a positive and significant relationship with GDP. The coefficient of GDP is 4.60 while the value of variance is 2.80 . On the other hand, the response variable labor migration has a negative but significant relationship with explanatory variable unemployment. There is a long-run relationship between labor migration, GDP, and unemployment. The result indicates the no relationship between labor migration and inflation rate.

Moreover, the R2 value of labor migration is 0.42 , GDP, inflation rate and unemployment $0.37,0.17,0.34$ and adjusted $\mathrm{R} 2$ value is $0.23,0.18,-0.08$ and 0.14 . it indicates that the residual plots are quite close to the regression line. The F-statistics value is $2.30,1.92,0.66$, and 1.72 respectively, while Log-likelihood value is 1.67, 109.5, 15.68 , and 5.85 .

Table-6. Vector Error Correction Estimation

\begin{tabular}{|c|c|c|c|c|}
\hline Error Correction & D(MIGRATION & $\mathrm{D}(\mathrm{GDP})$ & D(INFLATION & D(UNEMPLOYMENT \\
\hline CointEq1 & $\begin{array}{l}-0.251795 \\
(0.08604) \\
{[-2.92655]}\end{array}$ & $\begin{array}{l}0.013516 \\
(0.00541) \\
{[2.49948]}\end{array}$ & $\begin{array}{l}0.195774 \\
(0.13428) \\
{[1.45796]}\end{array}$ & $\begin{array}{l}0.062290 \\
(0.07729) \\
{[0.80593]}\end{array}$ \\
\hline D(MIGRATION(-1)) & $\begin{array}{l}0.348140 \\
(0.15330) \\
{[2.27099]}\end{array}$ & $\begin{array}{l}-0.004273 \\
(0.00963) \\
{[-0.44352]}\end{array}$ & $\begin{array}{l}-0.068935 \\
(0.23925) \\
{[-0.28813]}\end{array}$ & $\begin{array}{l}0.039836 \\
(0.13771) \\
{[0.28928]}\end{array}$ \\
\hline D(MIGRATION $(-2))$ & $\begin{array}{l}-0.021404 \\
(0.16778) \\
{[-0.12757]}\end{array}$ & $\begin{array}{l}-0.012430 \\
(0.01055) \\
{[-1.17874]}\end{array}$ & $\begin{array}{l}0.088644 \\
(0.26186) \\
{[0.33852]}\end{array}$ & $\begin{array}{l}0.205316 \\
(0.15072) \\
{[1.36220]}\end{array}$ \\
\hline $\mathrm{D}(\mathrm{GDP}(-1))$ & $\begin{array}{l}4.604680 \\
(2.80760) \\
{[1.64007]}\end{array}$ & $\begin{array}{l}0.037503 \\
(0.17645) \\
{[0.21253]}\end{array}$ & $\begin{array}{l}3.314130 \\
(4.38181) \\
{[0.75634]}\end{array}$ & $\begin{array}{l}-1.970112 \\
(2.52212) \\
{[-0.78113]}\end{array}$ \\
\hline $\mathrm{D}(\mathrm{GDP}(-2))$ & $\begin{array}{l}0.238470 \\
(2.52743) \\
{[0.09435]}\end{array}$ & $\begin{array}{l}0.109484 \\
(0.15885) \\
{[0.68925]}\end{array}$ & $\begin{array}{l}-1.403545 \\
(3.94455) \\
{[-0.35582]}\end{array}$ & $\begin{array}{l}-2.576992 \\
(2.27044) \\
{[-1.13502]}\end{array}$ \\
\hline $\begin{array}{l}\text { D(INFLATION_RATE(- } \\
\text { 1)) }\end{array}$ & $\begin{array}{l}-0.385043 \\
(0.11848) \\
{[-3.24974]}\end{array}$ & $\begin{array}{l}0.018734 \\
(0.00745) \\
{[2.51578]}\end{array}$ & $\begin{array}{l}0.027983 \\
(0.18492) \\
{[0.15133]}\end{array}$ & $\begin{array}{l}0.041865 \\
(0.10644) \\
{[0.39334]}\end{array}$ \\
\hline $\begin{array}{l}\text { D(INFLATION_RATE(- } \\
\text { 2)) }\end{array}$ & $\begin{array}{l}-0.182183 \\
(0.15069) \\
{[-1.20900]}\end{array}$ & $\begin{array}{l}0.004652 \\
(0.00947) \\
{[0.49123]}\end{array}$ & $\begin{array}{l}0.028071 \\
(0.23518) \\
{[0.11936]}\end{array}$ & $\begin{array}{l}-0.130043 \\
(0.13537) \\
{[-0.96067]}\end{array}$ \\
\hline D(UNEMPLOYMENT(-1)) & $\begin{array}{l}-0.067374 \\
(0.19526) \\
{[-0.34506]}\end{array}$ & $\begin{array}{l}0.003516 \\
(0.01227) \\
{[0.28651]}\end{array}$ & $\begin{array}{l}-0.271336 \\
(0.30474) \\
{[-0.89040]}\end{array}$ & $\begin{array}{l}-0.434038 \\
(0.17540) \\
{[-2.47453]}\end{array}$ \\
\hline D(UNEMPLOYMENT(-2)) & $\begin{array}{l}-0.169617 \\
(0.17771) \\
{[-0.95448]}\end{array}$ & $\begin{array}{l}-0.007783 \\
(0.01117) \\
{[-0.69683]}\end{array}$ & $\begin{array}{l}-0.027770 \\
(0.27734) \\
{[-0.10013]}\end{array}$ & $\begin{array}{l}-0.068383 \\
(0.15964) \\
{[-0.42837]}\end{array}$ \\
\hline $\mathrm{C}$ & $\begin{array}{l}-0.046285 \\
(0.09910) \\
{[-0.46707]}\end{array}$ & $\begin{array}{l}0.020094 \\
(0.00623) \\
{[3.22630]}\end{array}$ & $\begin{array}{l}-0.043503 \\
(0.15466) \\
{[-0.28128]}\end{array}$ & $\begin{array}{l}0.115014 \\
(0.08902) \\
{[1.29201]}\end{array}$ \\
\hline R-squared & 0.416728 & 0.374442 & 0.171959 & 0.347625 \\
\hline Adj. R-squared & 0.235712 & 0.180303 & -0.085019 & 0.145164 \\
\hline Sum sq. resids & 2.095461 & 0.008277 & 5.104055 & 1.690979 \\
\hline S.E. equation & 0.268807 & 0.016894 & 0.419526 & 0.241474 \\
\hline F-statistic & 2.302168 & 1.928731 & 0.669158 & 1.716997 \\
\hline Log likelihood & 1.675260 & 109.5891 & -15.68484 & 5.857349 \\
\hline Akaike AIC & 0.426910 & -5.107135 & 1.317171 & 0.212444 \\
\hline Schwarz SC & 0.853464 & -4.680581 & 1.743726 & 0.638998 \\
\hline Mean dependent & 0.089606 & 0.021303 & -0.006926 & 0.027955 \\
\hline S.D. dependent & 0.307477 & 0.018660 & 0.402754 & 0.261173 \\
\hline
\end{tabular}

Source: Ministry of trade and Commerce Pakistan 
VEC Residuals

EMIGRATION Residuals

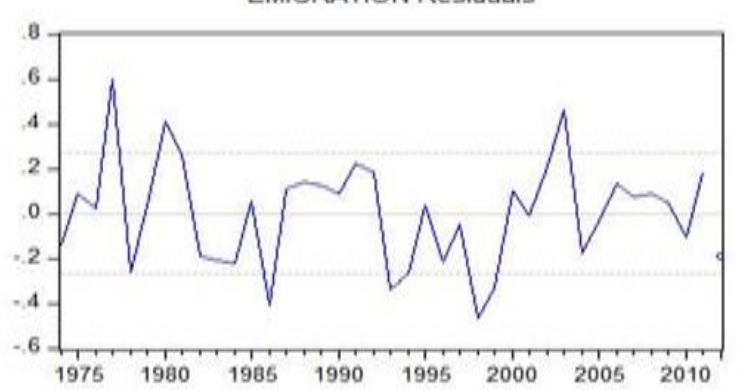

INFLATION_RATE Residuals

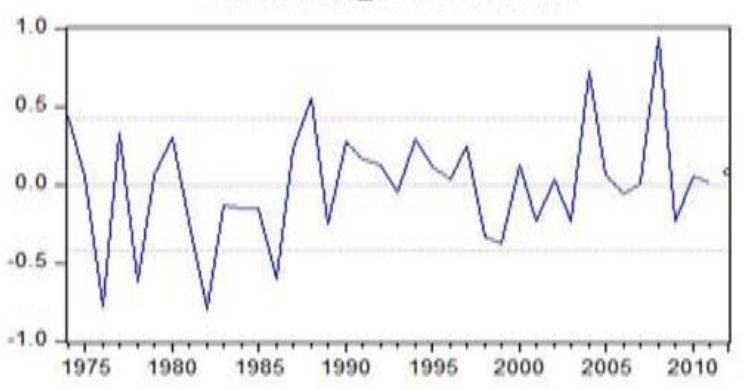

GDP Residuals

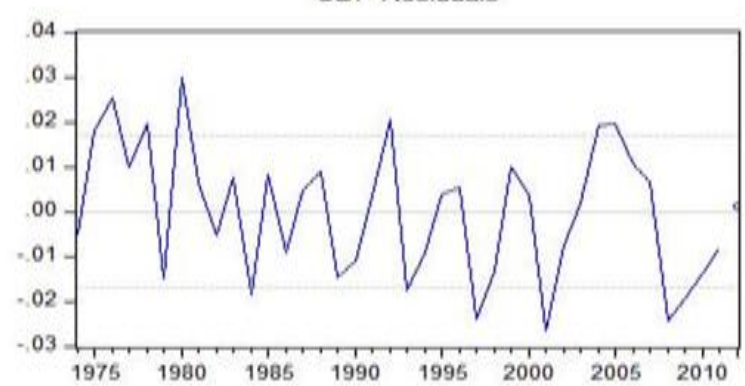

UNEMPLOYMENT Residuals

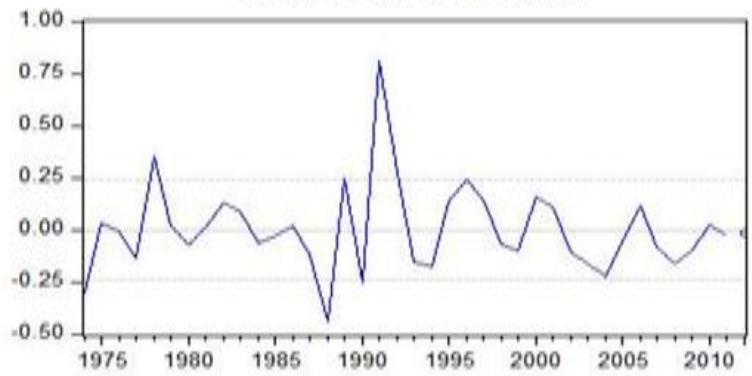

\subsection{Simple Regression Model}

Historically, when labor migration outflow increasing unemployment decreasing. Our study found that the response variable labour migration has a positive relationship which indicating labor migration increases unemployment. The reason is that a higher number of Pakistani labor in the Gulf region were deported due to consistently oil decline prices. The economic crises significantly affected Pakistani labor losses their jobs and deport from the Arab countries Simple regression model shows the relationship and significance value of the variables. We found that GDP has a positive and significant relationship with the response variable labor migration. When labor migration outflow increase GDP will increase in the form of labor-sending remittances. On the other hand, the response variable labor migration has a negative but statistically significant relationship with explanatory variable unemployment. It indicates when labor migration outflow increases the unemployment will decrease and vice versa. Moreover, we did not find any relationship between labor migration and inflation rate.

Table-7. Simple Regression Model

\begin{tabular}{l|l|l|l|l}
\hline Variable & Coefficient & Std. Error & t-Statistic & Prob. \\
\hline GDP & 1.550808 & 0.116755 & 13.28257 & $0.000^{* * *}$ \\
\hline INFLATION_RATE & 0.112327 & 0.222581 & 0.504657 & 0.6164 \\
\hline UNEMPLOYMENT & 0.849929 & 0.304895 & 2.787614 & $0.007^{* * *}$ \\
\hline Source: Ministry of trade and Commerce Pakistan
\end{tabular}

\section{Conclusion}

This paper has focused on how labor migration gives effect to economic development in emergent ones as sending nations from the viewpoint of the human capital. We analyzed the impact of labor migration on (GDP) and unemployment and determined the factors causing labor emigrants. The results of the regression analysis based on the relationship between labor migration, (GDP) and unemployment. We found that labor migration has a positive and significant relationship with GDP while a negative but statistically significant relationship with unemployment. On the other hand, there is no relationship between labor migration and inflation rate. The outcomes suggested that when the labor migration increases the GDP will increase vice versa. Alternatively, based on the previous literature when the labor migration increases the ratio of unemployment decreases. But in our study, we found a positive relationship between explanatory variable labor migration and unemployment. This result suggests to us that a significant number of Pakistani workers have been deported from the Gulf Cooperation Council (GCC) countries due to economic crises. Our analysis shows a strong consistent correlation between labor migration and GDP.

Overall, the conclusion of our paper approach comprises of macroeconomic development indicators such as unemployment, inflation rate, Gross Domestic Product (GDP) and labor migration. Based on the result of table 5 . We have stated that the relationship between labor migration, (GDP) and unemployment was clearly proved at all levels.

\section{References}

Artuç, E. and J. McLaren, 2015. Trade policy and wage inequality: A structural analysis with occupational and sectoral mobility. Journal of International Economics, 97(2): 278-294.Available at: https://doi.org/10.1016/j.jinteco.2015.06.001.

Awad, I., 2009. The global economic crisis and migrant workers: Impact and response (No. 433612). International Labour Organization.

Azam, F.-I., 1995. Emigration dynamics in Pakistan. International Migration, 33(3-4): 729-765.Available at: https://doi.org/10.1 11 1/j.14682435.1995.tb00039.x.

Braun, S. and J. Scheffel, 2007. Does international outsourcing depress union wages? : Humboldt University Berlin, Faculty of Business and Economics.

Chiswick, B.R., Y.L. Lee and P.W. Miller, 2005. A longitudinal analysis of immigrant occupational mobility: A test of the immigrant assimilation hypothesis. International Migration Review, 39(2): 332-353.Available at: https://doi.org/10.1111/j.17477379.2005.tb00269.x. 
Davidson, C., S.J. Matusz and A. Shevchenko, 2008. Outsourcing Peter to pay Paul: High-skill expectations and low-skill wages with imperfect labor markets. Macroeconomic Dynamics, 12(4): 463-479.Available at: https://doi.org/10.1017/s 1365100508070247.

Fassmann, H. and C. Hintermann, 1998. Potential East-West migration. Europe, 6(1): 59-72.

Felbermayr, G., J. Prat and H.-J. Schmerer, 2011. Globalization and labor market outcomes: Wage bargaining, search frictions, and firm heterogeneity. Journal of Economic Theory, 146(1): 39-73.Available at: https://doi.org/10.1016/j.jet.2010.07.004.

Firpo, S., N. Fortin and T. Lemieux, 2011. Occupational tasks and changes in the wage structure.

Glinskienè, R. and E. Petuškienè, 2009. The global economical crisis impact on the processes of Lithuanian reemigration and brain drain. Economics and Management, 14: 763-771.

Granger, C.W. and P. Newbold, 1974. Spurious regressions in econometrics. Journal of Econometrics, 2(2): 111-120.Available at: https://doi.org/10.1016/0304-4076(74)90034-7.

Hailu, Z.A., 2010. Impact of foreign direct investment on trade of African countries. International Journal of Economics and Finance, 2(3): 122-133.Available at: https://doi.org/10.5539/ijef.v2n3p122.

Halfacree, K., 2004. A Utopian imagination in migration's terra incognita? Acknowledging the non-economic worlds of migration decisionmaking. Population, Space and Place, 10(3): 239-253.Available at: https://doi.org/10.1002/psp.326.

Hirose, N., 1994. International labor migration and its economic effects. Asia-Pacific Review, 1(1): 39-57.Available at: https://doi.org/10.1080/13439009408719881.

Hughes, G. and B. McCormick, 1994. Did migration in the 1980s narrow the North-South divide? Economica, 61(244): 509-527.Available at: https://doi.org/10.2307/2555036.

Kenen, P., 1969. The theory of optimum currency areas: An eclectic view. Monetary Problems of the International Economy, 5 1(4): 41-60.

Khan, Y., M. Wang and T. Hassan, 2018. Foreign direct investment, economic growth and trade: An empirical analysis from Pakistan. Le Travail Humain, 81(3): 1735-1742.

Koser, K., 2010. The impact of the global financial crisis on international migration. Whitehead Journal of Diplomacy and International Relations, 11: 297-320.

Krugman, P., 1991. Increasing returns and economic geography. Journal of Political Economy, 99(3): 483-499.Available at: https://doi.org/10.1086/261763.

Kumpikaite, V. and I. Zickute, 2012. Synergy of migration theories: Theoretical insights. Inzinerine Ekonomika-Engineering Economics, 23(4): 387-394.Available at: https://doi.org/10.5755/jo1.ee.23.4.1240.

Meyer, D. and A. Shera, 2017. The impact of remittances on economic growth: An econometric model. Economia, 18(2): 147-155.Available at: https://doi.org/10.1016/j.econ.2016.06.001.

Mixon, J.F.G., 1992. Factors affecting college student migration across states. International Journal of Manpower, 13(1): 25-32.Available at: https://doi.org/10.1108/eum0000000000900.

Moore, M.P. and P. Ranjan, 2005. Globalisation vs skill-biased technological change: Implications for unemployment and wage inequality. The Economic Journal, 1 15(503): 391-422.Available at: https://doi.org/10.1111/j.1468-0297.2005.00994.x.

Mundell, R.A., 1961. A theory of optimum currency areas. The American Economic Review, 51(4): 657-665.

Noman, O., 1991. The impact of migration on Pakistan's economy and society. In Economy and Culture in Pakistan. London: Palgrave Macmillan. pp: 77-96.

Otoiu, A., E. Titan and R. Dumitrescu, 2014. Internal and international migration: Is a dichotomous approach justified? Procedia-Social and Behavioral Sciences, 109: 1011-1015.Available at: https://doi.org/10.1016/j.sbspro.2013.12.581.

Otrachshenko, V. and O. Popova, 2014. Life (DIS) satisfaction and the intention to migrate: Evidence from central and Eastern Europe. The Journal of Socio-Economics, 48: 40-49.Available at: https://doi.org/10.1016/j.socec.2013.09.008.

Ottaviano, G.I., G. Peri and G.C. Wright, 2013. Immigration, offshoring, and American jobs. American Economic Review, 103(5): 19251959.Available at: https://doi.org/10.1257/aer.103.5.1925.

Phongpaichit, P., 1990. The new wave of Japanese investment in ASEAN: Determinants and prospects. Institute of Southeast Asian.

Root, F.R., 1994. Entry strategies for international markets. New York: Lexington Books

Sjaastad, L.A., 1962. The costs and returns of human migration. Journal of Political Economy, 70(5, Part 2): 80-93.Available at: https://doi.org/10.1086/258726.

Todaro, M.P., 1969. A model of labor migration and urban unemployment in less developed countries. The American Economic Review, 59(1): 138-148.

Valiūnienè, V.K., 2016. Migration as the way for better employment perspectives: Case of European union. International Journal of Social Science and Humanity, 6(9): 728-733.Available at: https://doi.org/10.7763/ijssh.2016.v6.727-733. 